\title{
KARYA SENI: SELINTAS STUDI KASUS KEBAHASAAN TERHADAP PROSES KREATIF PEMBERIAN JUDUL
}

\author{
Purwito *)
}

ABSTRACK

The title is a name of a work of art. In the creative process, the title can be given through two strategies, namely before the artwork is created or after the work is completed. Categorically, the title can be classified into various. The classification can be made based on the type or structure. Based on the type, classification can be divided into three categories, namely noun, verb, or adjective, while based on its structure can be divided into four categories, namely letter, word, phrase, and sentence.

The approach applied in this analysis is linguistic approach, arguing that the subject title of the artwork is definitely using the code system prevailing in the language. As the result, there are two categories, namely the title of the artwork that is monointerpretabel and multiinterpretabel.

Key words : Art work, title of art work, and linguistic study.

\section{ABSTRAKSI}

Judul adalah sebuah nama karya seni. Dalam proses kreatif, judul dapat diberikan melalui dua strategi, yaitu sebelum karya seni dibuat atau setelah karya selesai. Secara kategoris, judul dapat diklasifikasikan menjadi bermacam-macam. Klasifikasi itu dapat dibuat berdasarkan jenis atau strukturnya. Berdasarkan jenisnya, dapat dibedakan menjadi tiga kategori, yaitu nomina, verba, atau ajektiva, sedangkan berdasarkan strukturnya dapat dibedakan menjadi empat kategori, yaitu huruf, kata, frasa, dan kalimat.

Pendekatan yang diterapkan dalam analisis ini adalah menggunakan pendekatan lingusistik, dengan alasan bahwa perihal judul karya seni pasti menggunakan sistem kode yang berlaku dalam bahasa. Hasilnya terdapat dua golongan, yaitu judul karya seni yang bersifat monointerpretabel dan multiinterpretabel.

Kata kunci: karya seni, judul karya seni, dan studi kebahasaan.

PENDAHULUAN

Berbicara tentang karya seni, dan pembicaraan pada kali ini berada dalam konteks yang lebih luas, maka karya seni dapat dikategorikan ke dalam sistem komunikasi, khususnya sebagai media. Untuk itu, maka istilah "bahasa rupa"

\footnotetext{
* Purwito (purwito_atmojo@yahoo.co.id), Staf Pengajar Program Studi Kriya Seni, Jurusan Kriya, Fakultas Seni Rupa, Institut Seni Indonesia Yogyakarta.
} 
menjadi sesuatu istilah yang sudah tidak asing lagi. Istilah "bahasa" diarahkan untuk mewakili konsep "komunikasi" dan "rupa" untuk mewakili konsep "media". Dalam arti bahwa "bahasa rupa" diarahkan untuk menunjuk suatu pengertian terhadap 'media komunikasi yang menggunakan elemen rupa'.

Karya seni sebagai sebuah sistem komunikasi, maka akan mengisyaratkan kepada semuanya, baik seniman maupun apresiatornya, bahwa di dalamnya harus terlibat adanya sistem tatanan yang melingkupi berbagai hal, di antaranya adalah pengirim, media, pesan, pengurai, dan penerima pesan.

$$
\text { Lantas, yang menjadi }
$$

permasalahan di sini adalah apakah karya seni, baik seni drama, seni tari, seni lukis, seni kriya, dan lain-lain dapat dikatakan sebagai media komunikasi? Suatu asumsi teoritik jelas memang demikian, dan hal ini tidak ada yang memungkiri. Oleh karena itu, maka paling tidak karya seni sebagai media komunikasi dapat berfungsi secara ganda, yaitu sebagai media untuk melakukan integrasi personal (seniman dengan dirinya sendiri, yang dalam hal ini berfungsi sebagai media kontemplatif) atau media integratif antar seniman dengan apresiatornya.

Di dalam kaitannya dengan karya seni sebagai media interaksi dan integrasi, atau lebih luas lagi sebagai media komunikasi, maka untuk mempermudah proses komunikasi itu kemudian oleh seniman penciptanya karya seni diberi "judul". Untuk itu, permasalahan yang dibahas kali ini adalah berkisar "proses kreatif pemberian judul". Perihal "judul" di sini sudah barang tentu menjadi bagian integral dari kajian suatu bahasa. Oleh karenanya, kajian yang akan diterapkan untuk membahas permasalahan ini merupakan kajian kebahasaan (linguistik).

\section{Esensi Permasalahan}

Terdapat dua hal yang akan dibicarakan di sini, yaitu pertama juduljudul karya seni dan kedua adalah kajian kebahasaan yang akan digunakan sebagai sebuah ancangan dalam proses kreatif pemberian judul terhadap karya seni. Hal pertama merupakan subject matter yang akan dipecahkan, sedangkan hal kedua lebih merupakan sebuah ancangan pendekatan yang akan digunakan untuk memecahkan hal pertama.

Judul karya, secara selintas dapat disinonimkan dengan sebuah nama. Lebih lanjut, nama dapat juga dikatakan sebagai sebuah identitas. Namun, secara lebih khusus lagi nama dapat juga diartikan sebagai sebuah harapan bagi seniman terhadap dirinya sendiri maupun terhadap apresiatornya. Oleh karenanya, maka nama (dalam hal ini adalah judul karya) dapat dikatakan sebagai sebuah harapan atau doa.

Untuk itu, selanjutnya agar perihal judul karya seni dapat dikatakan sebagai sebuah media komunikasi seniman dengan apresiatornya maka kajian bahasa menjadi salah satu ancangan tepat untuk membahasnya. Hal ini sesuai dengan salah satu fungsi bahasa, yaitu sebagai media untuk menuangkan harapan atau doa, baik harapan dan doa untuk dirinya sendiri maupun orang lain. Sejenak kita kembalikan fungsi bahasa pada sebagai media harapan dan doa. 


\section{Ancangan Teoritik yang Digunakan}

Sebelum lebih lanjut pembicaraan ini diarahkan pada pembahasan proses kreatif pemberian judul karya seni, maka akan lebih baik jika diawali dengan pembicaraan tentang bahasa sebagai sebuah sistem komunikasi sekaligus digunakan sebagai ancangan kajian terlebih dahulu, sehingga pembicaraan ini akan berjalan lebih runtut dan mudah dirunut.

Berbicara tentang bahasa, maka bahasa dapat dikatakan sebagai sebuah media yang baik di dalam pergaulan antarmanusia. Dikatakan demikian karena pada prinsipnya bahwa bahasa merupakan media yang cukup representatif untuk penjasmanian pikir dan proses berpikir. Lebih lanjut dikatakan bahwa pergaulan antarmanusia adalah pertemuan secara total antara manusia satu dengan lainnya, manusia dalam keseluruhannya, antara jasmani dan rohaninya bertemu dan bergaul satu sama lain, yang kesemuanya itu di dalam realitasnya tidak dapat dilepaskan sedikitpun dari bahasa dengan segala fungsinya. Jadi, tanpa bahasa, pertemuan dan pergaulan secara personal dan interpersonal menjadi tidak akan sempurna. Dari realitas alamiah inilah dapat dilihat dan diakui bahwa memiliki peran yang amat penting dalam peristiwa komunikasi.

Perlu juga diungkapkan di sini, bahwa di dalam suatu proses komunikasi akan terdapat sistem tanda, lambang, atau simbol yang semua itu akan disepakati bersama oleh pihak-pihak yang berkomunikasi (komunikator dan komunikan). Sistem tanda, lambang, atau simbol tersebut memiliki nilai dan acuan yang sama bagi pihak-pihak yang berperan- serta dalam berkomunikasi. Lalu, bahasa sebagai sistem tanda atau simbol untuk kepentingan berkomunikasi akan benarbenar terlihat fungsinya apabila pikiran, gagasan, dan konsep yang diacu atau diungkapkan melalui kesatuan atau hubungan yang bervariasi dari sistem tanda atau simbol itu dimiliki dan dipahami secara bersama-sama oleh kedua belah pihak, yaitu penutur (komunikan) dan penanggap tutur (komunikator). Bahasa itu sendiri sebenarnya diperoleh dan dimiliki bersama sebagai sebuah warisan kebudayaan dari masyarakat tempat kita tumbuh.

Dalam kaitannya dengan bahasa sebagai sebuah sistem tanda, maka sistem bahasa apapun memungkinkan manusia manapun dapat berbicara tentang sesuatu walau sedang tidak berada di lingkungan yang dipijak. Manusia pun bisa membicarakan sesuatu peristiwa yang sudah terjadi atau bahkan yang akan terjadi. Hal ini sangat dimungkinkan karena pada dasarnya di dalam bahasa itu terdapat daya simbolik untuk membicarakan konsep apapun juga, termasuk di sini untuk membicarakan judul-judul karya seni, dan ini pulalah yang memungkinkan manusia memiliki daya penalaran (reasoning), sehingga dengan penalaran itu manusia dapat dengan utuh berintegrasi secara personal (dengan dirinya sendiri) maupun interpersonal berintegrasi dengan pihak-pihak lain. Proses interaksi dan integrasi ini dapat berjalan dengan baik melalui kemampuan atau daya simbolik yang dimiliki oleh bahasa tersebut.

Lebih lanjut masih berkaitan denga bahasa sebagai sistem simbol, 
Susanne K. Langer dalam bukunya berjudul Philosopy In a New Key secara prinsipial membedakan dengan tegas antara sign 'tanda' dengan symbol 'simbol'. Menurut Langer, dengan tegas bahwa tanda pada hakekatnya adalah merangsang subjek (penangkap tanda) untuk bertindak, sedangkan simbol itu melainkan lebih merupakan sebuah "wahana" bagi pemecahan atau pemahaman terhadap objek (1955: 49). Dapat disimpulkan di sini bahwa antara tanda dengan objeknya memiliki hubungan yang sangat sederhana, sebab satu tanda hanya untuk mewakili satu objek saja (dalam konteks istilah lain dalam ilmu bahasa dapat disejajarkan dengan istilah denotatif). Sebagai sebuah ilustrasi untuk memperjelas permasalahan ini adalah: di mana ada "asap" (signifiant/penanda) maka dapat dipastikan di situ pulalah pasti terdapat "api" (signife/petanda). Di pihak lain, disimpulkan bahwa simbol adalah sebuah "wahana" bagi konsepsi manusia terhadap sesuatu atau objek. "Merah putih" misalnya, secara kontekstual oleh manusia manapun atau negara manapun memiliki konsep yang berbeda-beda. Oleh negara tertentu, misalnya Indonesia, merah dapat dikonsepsikan sebagai sikap bangsa yang "berani", dan warna putih dikonsepsikan sebagai "suci" yang secara utuh "merah putih" sebagai warna bendera Indonesia dikonsepsikan sebagai ketegasan sikap keberanian bertindak atas dasar kesucian atau kebenaran. Kendatipun demikian, konsep seperti itu terhadap warna "merah putih" tidak akan sama dengan konsep negara lain yang memiliki bendera dengan unsur warna merah dan putih. Dengan demikian simbol di sini lebih bersifat konvensional yang arbitrer.

Selain daripada itu semua, Joel M. Charon dalam bukunya berjudul Symbolic Interactionism: An Introduction, An Interpretation, An Integration menegaskan bahwa sign lead to an authomatic response, they are not abitrary or conventional (1989: 50). Di pihak lain Langer mengatakan bahwa the sign is something to act upon, or mean to command action; the symbol is instrumen of thought (1955: 51). Kemudian Langer menyebutnya bahwa simbol secara formal dapat dibedakan ke dalam dua kategori besar, yaitu simbol yang bersfat diskursif dan simbol presentasional. Simbol diskursif ini paling representatif dapat dilihat secara jelas dalam sistem bahasa yang memiliki konstruksi secara konsekuen. Tiap simbol memiliki satu nama, sehingga deretan simbol yang tersusun menurut aturan sintaksis tertentu akan menghasilkan satu gambaran makna atau konsep mengenai satu pokok kenyataan tertentu. Di sini terdapat satu sistem yang tak terabaikan, jika tidak ditaati aturan atau sistem tersebut maka akan mengakibatkan tidak adanya struktur yang jelas sekaligus kaburnya makna dari simbol yang terstruktur tadi. Dapat diambil contoh sebuah kalimat yang terstruktur dengan tidak menaati hukum-hukum sintaksis yang berlaku pada suatu bahasa tertentu, maka dapat dipastikan kalimat tersebut akan kehilangan makna. Misalnya dalam bahasa Indonesia dapat dijumpai pola kalimat dengan struktur S-P-O, dengan secara normal $\mathrm{S}$ diisi dengan kata benda, $\mathrm{P}$ diisi oleh kata kerja, dan O biasanya diisi oleh kata benda. Kendatipun demikian, ternyata 
tidak semua kata benda secara tepat dapat mengisi fungsi $\mathrm{S}$ atau $\mathrm{O}$ dan tidak semua kata kerja pun tidak semua dapat mengisi fungsi P. Misalnya: "Anjing mengangkat sebuah mobil". Mesikpun "anjing" dan "mobil" adalah kata benda dan "mengangkat" adalah kata kerja, tetapi dalam struktur kalimat tersebut tidak akan memunculkan makna yang dapat dipahami dengan baik di dalam sebuah proses komunikasi. Terdapat konsep "keberterimaan logika" yang diabaikan dalam struktur bahasa Indonesia yang berlaku, yaitu adanya ketidakgayutan dengan aspek semantikalnya.

Simbol kedua menurut Langer adalah simbol presentasional. Simbol presentasional adalah simbol yang secara konstruktif harus dipahami secara bulat dan utuh. Simbol seperti ini merupakan simbol yang memiliki satu kesatuan yang tidak boleh dipisah-pisahkan. Antara elemen simbol yang satu dengan lainnya memiliki jalinan yang kuat sehingga menurut Langer simbol presentasional tidak boleh dimaknai dengan cara menguraikan unsur-unsurnya. Jadi, simbol seperti ini lebih menganut pada teori globalistik. Di dalam pembahasan kali ini paham yang akan digunakan sebagai ancangan pokok dalam pengkajian terhadap permasalahan judul adalah menggunakan teori yang pertama, bahwa semua yang berkaitan dengan judul-judul karya seni adalah hal yang tidak dapat dipisahkan dari persoalan kebahasaan atau linguistik. Semua akan mengacu pada sebuah struktur yang bersifat diskursif, unsur yang satu dengan unsur lainnya akan tertata membentuk sebuah struktur yang bersifat sintagmatik dan dapat diurai atas elemen-elemen yang membentuknya, sehingga semuanya memiliki makna yang dapat dipahami secara bersama, baik oleh komunikator maupur komunikan. Jadi, alasannya adalah bahwa judul-judul karya seni adalah berkaitan dengan struktur bahasa, sedangkan persoalan bahasa adalah contoh yang paling tepat untuk mewakili simbol diskursif.

Selain Susanne K. Langer dan Joel M. Charon, perlu juga di sini ditambah satu teori relevan untuk menunjang ketepatan ancangan pemecahan permasalahan yang akan digunakan, yaitu dengan menambahkan teori yang dipaparkan oleh Panuti Sujiman dan Aart van Zoest, tetapi bukan tentang simbol melainkan tentang tanda berserta hubungannya dengan referen yang dimaksudkan. Pemaparan ini dengan alasan bahwa tanda memiliki keluasan cakupan pembicaraan daripada simbol. Hal ini disampaikan tidak berarti bahwa struktur teori yang digunakan bersifat "mondar-mandir", namun berbicara tentang bahasa memang pada awalnya paling tepat berbicara tentang sistem tanda.

Panuti Sujiman dan Aart van Zoest menjelaskan paling tidak terdapat tiga jenis hubungan antara tanda dengan referennya, yaitu: pertama hubungan antara tanda dengan referennya merupakan hubungan yang mendasarkan pada aspek "kemiripan". Kemudian tanda yang demikian ini disebut "ikon". Kedua, hubungan antara tanda dengan referennya dapat pula muncul karena terdapatnya faktor "kedekatan" eksistensi, maka tanda yang demikian ini disebutnya sebagai "indeks". Adapun yang ketiga adalah hubungan itu dapat juga merupakan 
sebuah hubungan yang sudah terbentuk secara konvensional. Kemudian sistem tanda yang ketiga ini disebut dengan istilah "simbol" (1992: 8-9 cf Benny Hoetoro Hoed, 1994: 133).

Dengan demikian Panuti Sujiman dan Aart van Zoest mengisyaratkan kepada kita bahwa simbol itu ternyata berada pada klasifikasi hubungan yang ketiga. Jadi, simbol tidak lain juga merupakan bagian dari sistem tanda yang dibuat berdasarkan sistem konvensi. Senada dengan pernyataan Joel $M$. Charon yang menjelaskan bahwa simbol adalah tanda yang dibuat oleh masyarakat berdasarkan sistem konvensi yang dinyatakan secara arbitrer, disepakati, dan diberi pengertian dalam interaksinya. Symbol are social. They are defided in interaction, not established in nature. People make them, and people agree on what they shall stand for. Some call symbols "conventionale" (1989: 40).

Berbicara tentang judul karya sebagai sebuah simbol, maka dapat dikatakan bahwa judul karya seni dapat berfungsi sebagai "wahana" pemahaman konsep penanggap (komunikan/apresiator) terhadap objek sebagaimana dimaksudkan oleh penutur (komunikator/seniman) yang bersifat transindividual atau antarpersonal. Namun demikian, dalam kaitannya dengan judul sebagai media untuk merefleksikan konsep estetik yang berada dalam internal seniman, maka hal ini berkaitan dengan struktur kebahasaan yang bersifat individual. Dengan demikian, terdapat dua hal besar tentang relasi kebahasaan yang berkaitan dengan judul karya. Untuk itu, agar menjadi lebih jelas berikut ini dipaparkan bagan mengenai dua jenis relasi tersebut.

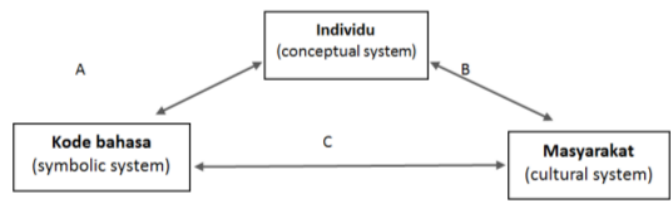

Bagan Relasi Kebahasaan (Alwasilah, 1985: 89).

Relasi A merupakan relasi yang bersifat individual-internal. Dalam hal ini yang terlibat adalah diri seniman sendiri yang di dalam peristiwa komunikasi penutur (seniman) baru berada dalam proses berkomunikasi dengan dirinya sendiri untuk menyusun konsep atau gagasan yang ada dalam batin atau pikirannya (sebagai aspek deep structure) melalui satuan-satuan kebahasaan (aspek surface structure). Sudah barang tentu bahwa jika sudah dikomunikasikan secara interpersonal, maka tak lepas dari sebuah harapan agar gagasan penutur atau seniman dapat diterima atau diakui eksistensinya oleh apresiator. Relasi A ini akan menghasilkan sebuah ide yang nantinya akan berkaitan dengan pemberian judul terhadap sebuah karya seni hasil ciptaannya. Jadi, agak mendahului bahwa relasi A lebih berdekatan dengan proses kreatif seniman dalam penamaan sebuah karya seni. Secara khusus sebetulnya relasi $A$ ini lebih tepat menjadi teba dari ancangan psikolingustik.

Adapun relasi B memberikan gambaran tentang hubungan antara seniman sebagai pencipta karya seni dengan apresiatornya (penikmat). Oleh karena itu, relasi B ini sudah merupakan peristiwa komunikasi secara interpersonal yang bisa saja peristiwa ini berada di dalam sebuah acara pameran atau pertunjukan/pergelaran karya seni. Di dalam relasi ini, apresiator berusaha memberikan interpretasi terhadap apa 
yang digagas/dicipta oleh seniman melalui komposisi estetik elemen-elemen visual, gerak, nada, ataupun suara. Interpretasi ini dapat muncul secara denotatif maupun konotatif. Hal itu tergantung dari komposisi elemen estetik yang digunakan oleh seniman serta sistem kode bahasa yang diungkapkan melalui sebuah judul karya yang telah ditetapkannya.

Dengan demikian, relasi B akan memberi gambaran bahwa penutur/seniman berusaha melakukan sosialisasi konsep individualnya (bisa juga konsep kolaboratif) ke dalam konteks transindividual (interpersonality), sehingga apa yang menjadi gagasan atau konsep seniman itu dapat diapresiasi oleh masyarakat (human social life). Berhubung relasi $B$ ini menunjukkan adanya hubungan seniman dengan apresiatornya (meski ada kemungkinan besar bahwa hubungan itu hanya sebatas antara karya seni dengan apresiatornya, tidak secara langsung dengan pihak senimannya), maka ancangan teoritik yang paling tepat diterapkan dalam permasalahan ini adalah ancangan sosiolinguistik.

Selanjutnya adalah relasi C. Relasi $\mathrm{C}$ menunjukkan adanya hubungan antara masyarakat (dalam hal ini disebut penikmat/apresiator) dengan karya seni melalui sebuah judul yang ditetapkan oleh seniman. Judul karya adalah salah satu bentuk komposisi satuan lingusitik yang bisa saja terstruktur secara sintagmatik atau mungkin hanya sekedar terbentuk secara morfologik belaka. Mudahnya, judul karya seni itu dapat berupa frase, kalimat, atau hanya merupakan sebuah kata sahaja, atau bahkan hanya sebuah huruf. Misalnya karya puisi terkenal karya Sutarji Cholsum
Bahri yang hanya diberi judul dengan menggunakan satuan linguistik berupa bunyi, yaitu $Q$. Puisi ini pada zamannya sangat mengundang diskusi di kalangan mahasiswa sastra, karena judul karya puisi ini dipandang sangat multiinterpr etabel. Berhubung relasi $\mathrm{C}$ ini lebih didominasi pada hubungan antara apresiator dengan judul karya seni, dalam konteks interpretasi terhadap judul (-judul), maka ancangan teoritik yang paling tepat diterapkan adalah pendekatan semantik. Di sini diharapkan bahwa hubungan antara sistem konseptual individu seniman yang diungkapkan melalui sistem kode bahasa dengan dengan sistem kultural masyarakat akan dapat difokuskan melalui proses pendayagunaan bahasa.

\section{Selintas Permasalahan tentang Judul Karya Seni}

Berbicara tentang judul karya seni, maka hal itu merupakan sebuah komposisi satuan lingual yang merepresentasikan sebuah konsep atau makna (sebagai fungsi pertama) yang berbentuk struktur morfologik atau sintaktik. Selanjutnya, jika judul sebagai konsep maknawi dari suatu karya seni itu disosialisasikan, maka judul sebagai salah satu sistem kode bahasa akan berfungsi strategis sebagai "wahana" pemahaman konsepsi bagi penikmat/apresiator terhadap objek (dalam hal ini karya seni). Objek di sini dapat memiliki dua aspek pokok, yaitu: pertama adalah karya seni yang di dalam hal ini dapat merupakan sebuah simbol yang bersifat presentasional dan aspek kedua adalah judul karya yang lebih tepat merupakan sistem kode bahasa yang lebih bersifat diskursif. 
Selanjutnya, para seniman di dalam berolah seni jelas berada dalam proses bereksploitasi dan eksplorasi pengalaman-penglaman batin, baik pengalaman batin itu merupakan pengalaman tentang keindahan maupun ketidakindahan, kemapanan maupun ketidakmapanan, keharmonisan mapun ketidakharmonisan, dan lain-lain. Dua kutub pengalaman tersebut kemudian diungkapkan/divisualisasikan ke dalam bentuk karya-karya seni melalui kemampuan teknis dan kemampuan estetis yang dapat dinikmati oleh masyarakat luas.

Eksplorasi terhadap pengalaman batin dan di luar batin seniman yang kemudian divisualisasikan/dipresentasikan dapat juga merupakan tanggapan internal maupun eksternal terhadap hal-hal atau suatu peristiwa yang pernah atau sedang terjadi, baik itu merupakan peristiwa alamiah maupun buatan, sosiologis maupun politis, dan lain-lain. Khusus dalam konteks seni rupa, visualisasi tersebut dapat berupa struktur atau komposisi dari garis, bidang, warna, ruang, tekstur, dan lain-lain. Dalam tataran presentasional; garis, warna, bidang, tekstur, dan lain-lain tersebut belum berkonsep tentang sesuatu. Baru setelah melalui proses komposisi, maka tatanan dari beberapa satuan estetis tersebut menjadi "bermakna".

Sebelum lebih lanjut dibahas, pada kesempatan ini ada baiknya dipaparkan bahwa terdapat perbedaan komposis yang perlu diketahui, yaitu perbedaan komposisi kebahasaan (nonseni) berada dalam konteks denotatum sign/symbol, sedangkan komposisi karya seni dapat merupakan perpaduan serasi antara denotatum sign/symbol dengan conotatum sign/symbol. Dalam kaitannya dengan sebuah judul karya seni sebagai sebuah nama, maka judul karya seni itu berada dalam jajaran sistem kode bahasa (simbol) yang bersifat denotatif, karena hal ini dimaksudkan oleh seniman sebagai wahana konseptual yang diharapkan dapat dipakai sebagai jembatan pemaknaan antara seniman dengan apresiatornya. Namun, tidak menutup pula bahwa judul pun dapat bersifat konotatif.

Perlu ditegaskan pula bahwa karya seni dengan judulnya memiliki perbedaan yang cukup berarti, kendatipun kedua hal tersebut secara internal sering, atau bahkan selalu "seiring dan sejalan", asalkan tidak anonimus. Di satu pihak (judul) dapat bersifat denotatif, meski sering mengarah ke multiinterpretabel, sedangkan di pihak lain (karya seni) dapat bersifat kedua-duanya, denotatif maupun konotatif, perpaduan dari keduanya. Dengan sifatnya yang demikian itu, maka sering muncul persepsi apresiator yang mengatakan bahwa semakin karya seni itu bersifat konotatif yang serba multiinterpretabel, maka karya seni itu akan semakin berkualitas. Namun demikian, kebenaran akan stigma seperti itu semuanya masih tergantung pada banyak pertimbangan dari berbagai aspek pendekatan.

Pada proses kreatif para seniman dalam hal pemberian judul, seniman dapat menempuhnya melalui dua srategi. Strategi pertama judul itu diberikan sebelum karya seni itu dibuat, sedangkan strategi kedua adalah judul itu ditetapkan terlebih dahulu sebelum karya seni itu 
mulai dibuat. Masing-masing memiliki konsekuensi yang berbeda. Apabila judul diberikan sebelum karya seni itu dibuat, maka strategis judul itu akan berfungsi mengikat. Adapun jika judul itu diberikan sesudah karya seni dicipta, maka menjadi sebaliknya, sehingga seringkali tidak menutup kemungkinan bahwa seniman dalam hal memberikan judul menjadi berubah-ubah. Strategi mana yang dapat dikatakan sebagai sebuah strategi yang benar. Jawabnya tergantung pada kebiasaan seniman, sehingga dalam hal pemberian judul tidak ada istilah strategi benar atau strategi salah. Keduanya bisa sangat sering terjadi.

Secara kategoris, judul-judul karya seni dapat digolongkan menjadi sangat bermacam-macam. Di antaranya adalah judul yang bersifat nominal, misalnya "Pemulung" (Asnul Bahri), "Kerbau dan Penggembala" (Tohir), dan "Bulan dan Rembulan (Husen Hendriyana). Judul yang bersifat verbal, misalnya "Menghadap kepadaNya" (Risman Marah), dan lain-lain. Di sisi lain, judul-judul karya seni dapat dibedakan berdasarkan strukturnya. Berdasarkan struktur, maka judul-judul karya seni dapat digolongkan menjadi beberapa, di antaranya adalah judul yang hanya berupa huruf, misalnya " $Q$ " untuk puisinya Sutarji Cholsum Bahri; judul yang berupa kata, misalnya "Smelekete" karya seni lukisnya Bob "Sick" Yudhita Agung; judul yang berupa frase atau kelompok kata, misalnya "Tragedi Sihka dan Winka"nya Sutarji C.B.; dan judul yang berupa kalimat, misalnya "Three Girl In the Bedroom" karya Ambarwati atau "Pak Karyo Iya Bilang mBoten" karya Darmanto Yatman.
Namun demikian, ternyata sering dijumpai karya-karya seni yang tidak diberi judul sama sekali atau hanya diberi judul sesuai dengan fungsinya belaka, misalnya Kap Lampu 1, Kap Lampu 2, Kap Lampu 3, Hiasan Dinding 1, Hiasan Dinding 2, Hiasan Dinding 3, dan seterusnya. Bisa juga hal seperti ini disengaja oleh senimannya untuk memberikan keleluasaan apresiator memberikan interpretasinya. Terserah apresiator mau berkomentar apa tentang judul tersebut, apa yang terdapat di dalam konsep estetis seniman tentang karya seninya. Ataukah justru hal ini merupakan "kealpaan" seniman dalam proses kreatifnya, sehingga pesan yang disampaikan melalui karya seni itu menjadi sangat berkurang.

Pemahaman terhadap karyakarya seni yang tak berjudul akan menjadi sangat multiinterpretabel, kendatipun salah satu sifat karya seni adalah demikian ini. Oleh karena itu, dalam proses pemahamannya sangat dibutuhkan sebuah ground of conotatum/ denotatum sign/symbol yang berlaku pada konteks di mana seniman itu berada. Hal ini dimaksudkan agar konsep maknawi/simbolis yang ditangkap oleh para apresiator menjadi tidak jauh berbeda dengan konsep maknawi yang dimaksudkan oleh seniman penciptanya, meski hal ini pihak seniman tidak terlalu merisaukan atas komentar yang diberikan oleh apresiator. Terserah apresiator mau berkomentar bagaimana, justru semakin karya seninya dapat ditafsirkan bermacammacam, maka karya seninya akan semakin bagus, karena telah mengundang banyak diskusi dan banyak tafsir. Di samping itu semua, perlu juga ditandaskan bahwa 
seniman pada masa kini banyak sekali yang berusaha menghadirkan karya seninya dengan judul yang serba multiinterpretabel, sehingga responsi sepenuhnya diserahkan pada pihak apresiator. Meskipun begitu, tidak dapat dipungkiri juga bahwa melalui karya seni, seniman selain berusaha mengungkapkan keindahan jiwa secara visual estetis melalui sebuah komposisi "apik" dari elemenelemen seni, maka karya seninya dimuati juga dimensi pewartaan batin dan pikiran yang terobsesikan secara intens. Suatu contoh di sini dapat diambil sebuah karya berjudul "Bulan dan Rembulan"nya Husen Hendriyana. Melalui komposisi satuan visual warna, garis, bidang, tekstur, cahaya, dan elemen-elemen lainnya yang divisualisasikan ke dalam struktur intrinsik sekaligus ekstrinsik berdasarkan pengelaman estetis dan kemampuan teknisnya, Husen Hendriyana berusaha mencoba menawarkan konsep batin dan pikirannya bahwa "Hidup ini adalah ibadah". Oleh karena itu, responsi internal yang dipadukan dengan responsi eksternalnya, Husen Hendriyana ingin mengintegrasikan dirinya dengan konsep religiusitas sebagai pedoman dan pegangan hidup agar dirinya dapat memperoleh ketenangan jiwa.

\section{PENUTUP}

dari elemen-elemen estetis yang bersumber dari pengalaman-pengalaman internal maupun eksternal yang kehadirannya dapat berupa responsi seniman terhadap dirinya sendiri atau lingkungannya. Komposisi elemen estetis tersebut hadir dalam suatu karya seni yang kadang bisa bersifat donotatif (monointerpretabel) dan dapat pula bersifat konotatif (multiinterpretabel), dan lebih jauh lagi dapat pula hadir dalam perpaduan antara keduanya. Betapapun kemonointerpretabelan dan kemultiinterpretabelannya, maka antara komposisi elemen estetis dengan judul yang diberikan harus terdapat pula keselarasan konseptual secara logis.

Kendatipun demikian, dapat pula dikatakan bahwa di dalam karya seni sering terjadi deotomatisasi atau defamilierisasi, sehingga posisi ini akan seringkali menimbulkan penyimpanganpenyimpangan konvensi. Hal ini terjadi karena sistem simbol yang digunakan dalam karya seni merupakan simbol-simbol yang bersifat arbitrer. Namun, kesimpulan yang dapat diajukan di sini tetap menghendaki adanya keselarasan relasi antara konvensional dan nonkonvensional, antara denotasi dan konotasi, atau antara judul dan yang diberi judul. Bukannya relasi yang secara total secara arbitrer. Memang dalam hal ini terdapat konsepsi bahwa seni adalah untuk seni. Jika konsep ini dianut secara total, maka fungsi karya seni hanya berfungsi sebagai media komunikasi dalam satu arah, tidak ada pesan yang akan disampaikan kepada masyarakat luas. Untuk itu, perlu ada pembedaan secara tegas antara konsep arbitrer dan relasi arbitrer. 


\section{DAFTAR PUSTAKA}

Alwasilah, A, Chaedar. 1985. Sosiologi Bahasa. Bandung: Penerbit Angkasa.

Charon, Joel M.. 1989. Symbolic Interactionism: An Introduction, An Interpretation, An Integration. Englewood, New Jersey: Prentice Hall.

Chauchard, Paul. 1983. Bahasa dan Pikiran.

A. Widyamartaya (Penterj.). Yogyakarta: Penerbit Yayasan Kanisius.

Firth, Raymond. 1973. Symbol Public and Private. London: George and Unwin Ltd.

Hoed, Benny Hoedoro. 1994. "Dampak Komunikasi Periklanan: Sebuah Ancangan dari Segi Semiotika" dalam Seni: Jurnal Pengetahuan dan Penciptaan Seni. Tahun IV, Nomor 2, April 1994. Yogyakarta: BP ISI Yogyakarta.

Langer, Susanne K.. 1955. Philosophy In A New Key. New York: New American Library.

Noth, Winfred. 1990. Handbook of Semiotics. Bloominton and Indianapolis: Indiana University Press.

Sujiman, Panuti dan Aart van Zoest. 1992. Serba-serbi Semiotika. Jakarta: P.T. Gramedia Pustaka. 